\title{
Social media attacks on public health advocates
}

How big corporations are helping to fund the internet trolls

Martin McKee professor of European public health, London School of Hygiene and Tropical Medicine

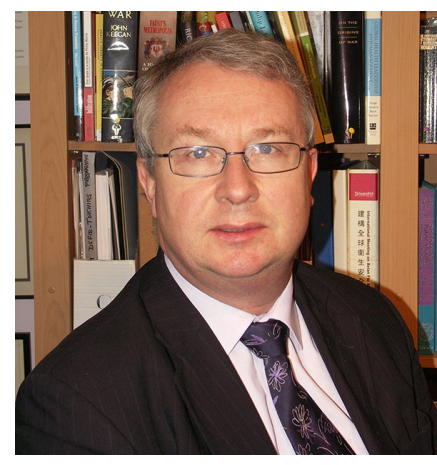

For those who advocate for healthy public policies, social media are both a blessing and a curse. They offer a means of communicating instantly to large audiences. Yet they also offer the opportunity for those seeking to undermine public health to undermine you. Your words are taken out of context and twisted. You are insulted and abused on Twitter. Most of us soon realise that this is the price to be paid for taking a stand and refuse to engage with our attackers, whose main aim seems to be to provoke a hostile response that they can ruthlessly exploit. We rapidly become adept at using Twitter's "block" function.

But who is behind these attacks? It is not always easy to know, as many shelter behind the anonymity afforded by the web.

Some are clearly extreme libertarians, opposed to any role for the state and, especially, anything that gets in the way of the right of informed adults to engage in activities that are likely to kill them prematurely. Some seem to be deeply troubled individuals, who in the past might have spent their days on a soap box in the marketplace, holding forth to anyone who was prepared to listen to them.

But some are professionals, paid by large corporations to attack others. Although this was long suspected, these suspicions have been strengthened by recent events in New Zealand. In August 2014 a New Zealand journalist, Nicky Hager, published a book entitled Dirty Politics. ${ }^{1}$ It was produced in conditions of great secrecy, given the explosive nature of the allegations it contained, and rapidly became a best seller there. Its primary source was a cache of emails sent or received by the author of the right wing "Whaleoil" blog, Cameron Slater. Most of the allegations concerned politics, linking attacks on opposition party politicians and civil servants to messages from senior politicians in the ruling National Party or those close to them, including unauthorised use of intelligence files. The then justice minister, Judith Collins, who was implicated in some of these allegations, eventually succumbed to widespread pressure and resigned. $^{2}$

While Dirty Politics is gripping reading simply on account of its tales of intrigue, it is of particular interest to anyone working in public health, as it makes allegations about some of those whose money was, albeit circuitously, paying Slater. They included tobacco, food, and alcohol companies. These companies had engaged a public relations consultant, Carrick Graham, the son of a senior National Party politician. Graham paid Slater a reported \$NZ6555 (£3180; €4160; \$US5080) a month to promote the interests of his clients, which included online attacks on those whose work threatened his clients' interests. Other payments came through Katherine Rich, head of the trade body the Food and Grocery Council, who, improbably, given her role as a spokesperson for the food and alcohol industry, had been appointed by the government to the board of the Health Promotion Agency.

The targets of these attacks included Doug Sellman, an eminent physician who headed New Zealand's National Addiction Centre. Sellman was a prominent critic of the activities of the alcohol industry. Of him Slater said, "Any ounce of credibility that this guy once had has long since evaporated," and, "Maybe it's time Doug has a quiet beer under a tree and learns to calm the f**k down." Another target was Wendyl Nissen, a columnist for the New Zealand Herald, who had criticised the use of artificial colours in soft drinks and processed foods. ${ }^{4}$

In some cases the apparent offence was no more than to report a story that the industry would like to go away. Matty McLean, a presenter for Television New Zealand, reported on the recall of a cream product contaminated by Escherichia coli. The Food and Grocery Council was concerned about the resulting publicity, and, as Hager's investigation showed, Graham emailed some text to Slater, which he published on his blog the next day with the heading "Calm down, move on," and continuing, "You'd think the plague had hit New Zealand ... People need 
to calm the $\mathrm{f}^{* *} \mathrm{k}$ down." ${ }^{, 5}$ Later that day Slater accused journalists such as McLean of "scraping the barrel" with this story.

Attacks such as this are not limited to New Zealand. Similar attacks have been made on British public health professionals, especially those active in tobacco control. Those responsible for other blogs and Twitter accounts employing similar tactics, many of which are remarkably prolific, are anonymous. In the light of the revelations from New Zealand, the public health community might reasonably be suspicious about who is really behind these activities.

Competing interests: MMcK has often been the target of attacks in blogs and on Twitter for his advocacy of public health. He was in New Zealand as a guest of the Association of Salaried Medical Specialists, occasionally a target of the Whaleoil blog, and spoke at its 25 th commemorative conference.

Commissioning and peer review: Commissioned; not peer reviewed.

1 Hager N. Dirty politics. Craig Potton Publishing, 2014

Judith Collins resigns as NZ justice minister over ties to blogger. Guardian 30 Aug 2014 www.theguardian.com/world/2014/aug/30/judith-collins-resigns-as-nz-justice-ministerover-ties-to-blogger.

3 Slater C. Confirmed: Doug Sellman has gone mad. Whaleoil blog. 27 Feb 2014. www. whaleoil.co.nz/2014/02/confirmed-doug-sellman-gone-mad/.

4 Nissen W. Tuning out: Dirty Politics and the blogs. New Zealand Herald 16 Sep 2014. www.nzherald.co.nz/nz/news/article.cfm?c_id=1\&objectid=11325097.

5 Slater C. Calm down, move on. Whaleoil blog. 14 Jan 2014. www.whaleoil.co.nz/2014/ 01/calm-move.

6 Slater C. The world is coming to an end? Whaleoil blog. 14 Jan 2014. www.whaleoil.co. nz/2014/01/world-coming-end.

Cite this as: BMJ 2014;349:96006

๑๑ BMJ Publishing Group Ltd 2014 